\title{
The Effectiveness of Frog Virtual Learning Environment in Teaching and Learning Mathematics
}

\author{
Seuk Yen Phoong ${ }^{1, *}$, Seuk Wai Phoong ${ }^{2}$, Kok Hau Phoong ${ }^{3}$ \\ ${ }^{1}$ Department of Mathematics, Faculty of Science and Mathematics, Sultan Idris Education University, Malaysia \\ ${ }^{2}$ Department of Operations and Management Information Systems, Faculty of Business and Accountancy, University of Malaya, \\ Malaysia \\ ${ }^{3}$ Faculty of Management and Information Technology, Sultan Azlan Shah University, Malaysia
}

Received August 8, 2019; Revised January 20, 2020; Accepted February 20, 2020

Copyright $\mathrm{O} 2020$ by authors, all rights reserved. Authors agree that this article remains permanently open access under the terms of the Creative Commons Attribution License 4.0 International License

\begin{abstract}
The Frog Virtual Learning Environment (Frog VLE) is a virtual learning medium that is one of the main agendas in today's educational landscape especially in Malaysia. The main objective of using Frog VLE is to simplify and enhance teaching and learning process. This study evaluated the effectiveness of Frog VLE in primary school using the Technology Acceptance Model. The study was carried out using a quasi-experimental design involving two groups; one control group and a treatment group. The former used the chalk-and-talk approach, while the latter used the Frog VLE approach. We administered a structured questionnaire to a primary school in Malaysia to elucidate the students' perspective on the usage of Frog VLE in teaching and learning process. The mean score analysis and paired- $t$ test were applied to the analysis, and the results showed that the majority of the students found that the Frog VLE tool is useful and effective for learning.
\end{abstract}

Keywords Chalk-and-Talk Approach, Frog Virtual Learning Environment, Primary School, Technology Acceptance Model, Virtual Learning

\section{Introduction}

Previously, teachers prefer to use chalk and talk in the classroom which getting less attention from the students. Hence, Frog Virtual Learning Environment (Frog VLE) is introduced to capture their attention and interest towards learning. This learning tool is applicable to all the subjects.

The Frog VLE is an innovation in education that falls in line with the development of technology introduced by the Ministry of Education (MoE) in Malaysia. The system was implemented in primary schools in Malaysia at mid-2013. Frog VLE is a cloud-based learning platform that link administrators, managers, school teachers, and students within a school's ecosystem [1]. This system is a learning content management system that allows teacher to provide materials to their students remotely. The network can be utilized by teachers, students and parents to share learning resources, for interactive learning, and dynamic communications.

Frog VLE is a communication platform between teachers and students. It provides a page with forums for each school, which can only be accessed by students and teachers of that school. The forums can be used as a discussion platform for the teachers and students. Schooling period is inadequate for students to inquire about the lessons or about things they do not understand. The Frog VLE forum facilitate teacher-student interactions post-school hours, which is expected to improve the overall performance of the students, in line with the policies outlined in the Malaysia Education Blueprint (PPPM) [2].

The Technology Acceptance model (TAM) was selected as a guideline to discuss the adoption and use of Frog VLE among teachers in schools. Frog VLE facilitates the formation of social networks among communities in school systems. Teachers will be able to assign tasks and homework via social sites hosted by Frog VLE, and the students can upload their work via the same platform for the teachers to grade. This will indirectly reduce the load of school bags while also propagating a paperless learning environment.

In addition, Frog VLE contains multiple aspects that can strengthen the understanding of the students. This system is also more student-centered learning, where students listen to detailed instructions pertaining to mathematical concepts, with the teachers serving as facilitators [3-5].

The usage of Frog VLE in teaching and learning is exciting as it provides students with the opportunity to actively participate in the teaching-learning process. 
According to the theory of constructivism, Frog VLE is suitable due to the fact that it emphasize the fact that teachers need to act as facilitators of learning [6]. On top of being fun, Frog VLE helps students understand the subject being taught in classrooms. Learning how to work a computer to facilitate being a part of the Frog VLE system will indirectly improve the cognitive and psychomotor development of students.

Moreover, Frog VLE is a learning aid that relevant to $21^{\text {st }}$ century learning. Educators would also have the opportunity to tailor the environment based on the learning goals while keeping the students interested [7]. This application is expected to produce highly skilled students in the subjects being taught via this platform.

The Frog VLE's learning involve being familiar with educational content on websites (video, image, educational resources) without being technically competent in building them [8]. Educational content on the internet such as videos or images would help students to learn, because the internet can deliver interactive content capable of keeping the students interested [9]. The multi-colored images increase students' concentration due to the fact that the brain becomes more attentive when exposed to colors. Internet content can also help students understand a lesson faster due to its pervasive use of visually stimulating content. Cheok et al. [10] posited that the use of electronic devices and the internet would increase students' propensity to use Frog VLE application.

In addition, teachers can diversify Mathematics teaching methods that are more suitable for different level students by using technology to carry out their teaching and learning activities [11]. The Frog Virtual Learning application is user friendly and this is important for teachers to avoid problems such as technical difficulties or schools with lack of technical assistance. In most school, teachers faced constraints when integrating knowledge and information technology into the teaching process because lack of technical assistance or have technical problems that cause interruptions in teaching and learning activities $[12,13]$. Thus, the implementation of Frog VLE application is hoped to help teachers to easily manage their lesson and integrated more graphical or video to enhance the teaching materials in classroom.

This study elucidates factors on students' usage of Frog VLE and its effectiveness from the perspective of students via teaching and learning in Mathematics. The objectives of this study are:

i. To quantify the students' perception on the effectiveness of Frog VLE in the context of learning.

ii. To analyze the difference in students' achievement between pre-test and post-test in a conventional classroom.

iii. To analyze the difference in students' achievement between pre-test and post-test for the use of Frog VLE in classrooms.

\section{Literature Review}

In education, the chalk and talk approach is act as a traditional approach because teachers only use whiteboards and markers pen when delivering knowledge [14]. This approach only allows one-way communication in which students are allowed to share their opinion or answer questions when the teacher asks [15]. Students are always required to copy what is written in the whiteboard. According to Jabeen and Ghani [16], the traditional approach or known as chalk and talk is less relevant to the needs of students today. Pupils are more interested if their learning process involved with activities or games. A positive impact can be obtained towards achieving educational goals through activities. This is because learning only occurs when what is taught gives meaning to the students.

In addition, the teaching method that implemented in teaching and learning was the main factor that affects students' perception towards Mathematics [17]. However, in reality is that some of the teachers still practice traditional approaches in teaching and learning which is the teacher-centered learning. This might demotivate the students to learn. Thus, Malaysian Government introduced Frog VLE as a platform to enhance students' understanding and knowledge.

Frog VLE is a web-based platform designed to support the teachers in managing student learning processes through online [18]. This application consists of communication equipment such as email, forum, discussion corner and tools to organize all teaching and learning administration processes. In addition, Frog VLE can be used to handle assessment such as tests and online quizzes, as well as information dissemination medium to students [19].

According to Rheingold [20], the Frog Virtual Learning Environment provide a great opportunity for communities to access the workshop materials and related information with the title given. Documents like presentation materials, articles as well as an additional list of resources available on-line from other web pages should be included.

The integration of Frog VLE in teaching can create a more sophisticated new learning environment in terms of learning methods and materials to attract students to learn Mathematics. The usage of Frog VLE applications in teaching and learning process is also one of the most exciting methods as it provides an opportunity for each student to participate actively in the activities [4].

In addition, Kumarawel [21] stated that Frog VLE is used to create a borderless learning environment and selfdirected learning for students with the presence of internet connectivity. The implementation of Frog VLE also aimed to enhance students' learning experience by leveraging the internet and technology to improve teaching and learning process.

According to the theory of constructivism, this method 
is suitable to be used as it emphasizes the need of teachers to act as facilitators to help and monitor learning and facilitating processes. Additionally, the use of Frog VLE application is not an activity that is just for fun, but it helps and gives students the opportunity to cultivate the environment according to the learning goals and facilitates the students' interest towards Mathematics. This Frog VLE application is expected to produce students with highintelligence and computer literacy that enable them to be at par with the developed countries.

Moreover, Frog VLE was introduced to attract students' attention and interest. This is because most of the students are recently cynical to the use of technologies such as smart phones, computers, laptops and other technology devices. We can increase the students' attention and focus on learning if we can use technology in teaching. Frog VLE's learning encompasses educational content on the website (video, image, educational resources, etc) and makes it a website, without the need for technical expertise. With educational content on the internet such as videos or images, students can focus and pay attention to learn it. This is because the internet content has the capability to deliver its contents by attaching interesting images and usually has a variety of colors. Attracting images and colors in learning can help pupils set their focus in learning because our brains tend to be active when exposed to color diversity [22]. In addition, the learning content that uploaded at the internet also helps students to understand a lesson faster. This is because the content uploaded in the internet included in the Frog VLE has an illustration or video that can express its effectiveness effectively.

Another important of the implementation of Frog VLE in teaching and learning process is to help teachers to monitor the forum, assignment, projects and achievement of students. With the help of Frog VLE, teachers can identify the level of understanding of students by giving them a virtual assignment, exercise or quiz for each chapter. The weaknesses of a student (such as misunderstanding the concept, carelessness, encoding, etc) in that chapter can be identifying through assignment, forum or quiz. Additionally, teachers also can monitor the performance of students via assessment given.

Frog VLE not only plays essential role to the students and teachers, this application also enables parents to share ideas and help their children learn through Frog VLE. This is because teachers, students and parents can share information or ideas through this application.

In addition, students can communicate with teachers and colleagues outside of school hours through Frog VLE. With this modern learning style, students will not be bored with the subject. This learning style also can encourage students to use Frog VLE in learning and this is expected to realize the goal of national education, and the concept of paperless teaching.

Frog VLE also provides personalized 'cloud storage' services to its users. This cloud storage service is provided by Google to assist Frog VLE users to store the digital information. With cloud storage, pupils can access the information that they have uploaded through smart phones, computers and laptops [23].

Moreover, Frog VLE offers a simple and flexible learning method. It is allowing learning process to happen anytime and anywhere. If this application integrated in the classroom, the student's position or arrangement is no longer a sign of importance as they interact with teaching materials and friends. The learning process may continue outside the classroom. Pupils can learn at their own pace in the environment they are comfortable with. It also allows all students to engage in learning environments. Therefore, there should be a guide for teachers to choose the suitability of material and time.

Malaysia cannot be left behind from other developing countries in providing the latest education system. In the era of mobility today, the opportunity wide open to design different learning, creating a community extensive learning, connecting people in real and virtual worlds, provide expertise on demand and support lifelong learning. Frog VLE is seen as an intermediate tool in the learning process.

\section{Research Methodology}

Frog VLE is used to capture students' interest towards learning through communication tools such as discussion through email, forum and discussion platform. However, the drawback of this teaching tool is that it needs learning through online. School or home needs to provide good online system/wifi to enable the students to learn Mathematics using Frog VLE through online.

The quasi-experimental design is suitable for studying the effectiveness of Frog VLE in teaching and facilitating learning. Quasi-experimental studies are commonly used to assess the effectiveness of a program/intervention [24]. It uses purposive sampling as a mode of choice to select respondents. An intervention will then be applied to one/more groups. The effect of the intervention(s) measured at the end of the study can be used to determine the cause and effect of the study. Participants will be randomly selected and distributed to the experimental and control groups. The advantage of a quasi-experimental study is that it can gauge the effectiveness of an intervention and its applicability in teaching Mathematics in the future.

The respondents of this study are students from a primary school in Selangor, Malaysia. This school is categorized as a medium-sized school where the total students are between 151 and 600 students. The target school is lack of infrastructure, facilities and the population density especially in urban areas. The aim of this study to select the target school is to find out whether the Frog VLE is suitable for a medium-sized school in Malaysia. This is because it may not suitable for the students to creative and 
critically thinking using virtual learning medium where they are not familiar with, in addition to conceptualize the Mathematics theories and calculation.

A total sample size of 40 students was involved. 20 students were designated as the control group, and 20 students were designated as the experimental group. Students in the former were exposed to the chalk-and-talk approach, while students in the latter group were exposed to the Frog VLE approach in the topic of Division for Year Five students.

\subsection{Quantitative Analysis}

In this study, the instrument that used to collect data is questionnaire. It was used to elucidate students' perceptions on the use of Frog VLE application. There are eight items used to test their perceptions based on 5-points Likert scale, ranging from Strongly Disagree (1) to Strongly Agree (5).

After developing a questionnaire, the validity of an instrument is measured to identify the consistency of the instrument. Table 1 shows the range of Cronbach alpha value and its level of reliability coefficient.

Table 1. Reliability Coefficients of Instrument

\begin{tabular}{|c|c|}
\hline Cronbach's Alpha & Value of Reliability \\
\hline$<0.67$ & Poor \\
\hline $0.67-0.80$ & Fair \\
\hline $0.81-0.90$ & Good \\
\hline $0.91-0.94$ & Very Good \\
\hline$>0.94$ & Excellent \\
\hline
\end{tabular}

(Source: Fisher [25])

Table 1 reveals the level of reliability coefficients for an instrument meanwhile Table 2 shows the level of achievement according to its marks obtained from both the control and treatment groups.

Table 2. Mean Score of the Students' Achievement

\begin{tabular}{|c|c|}
\hline Marks & Level of Achievement \\
\hline $80-100$ & A \\
\hline $65-79$ & B \\
\hline $50-64$ & C \\
\hline $40-49$ & D \\
\hline $0-39$ & E or Fail \\
\hline
\end{tabular}

The mean score can be obtained by referring to the research design of the study. Firstly, a pre-test will be given to both control and treatment groups. The treatment group was taught using the Frog VLE application while the control group was taught using the chalk and talk approach. Then, notes, videos, pictures or games about the topic Division are uploaded in Frog VLE applications before starting the lesson. This step only applied on the treatment group. Students from the treatment group were asked to read the notes and try to answer the questions using Frog VLE before the lesson.

Subsequently, teaching sessions were commenced for both groups on the topic of the Division. The treatment group was taught using the Frog VLE application while the control group was taught using the chalk and talk approach. After the lesson was conducted, a post-test is given to both groups of students. All marks were then carefully quoted to make comparisons between the results of pre- and post-test to identify the effectiveness of Frog VLE in classroom.

After analyse the results obtained, students are required to answer a questionnaire to investigate the students' interest toward the implementation of Frog VLE in the teaching and learning process. Table 3 shows the range of the mean score for interest of students towards Mathematics.

Table 3. Mean Score of the Students' Interest towards Mathematics

\begin{tabular}{|c|c|}
\hline Score & Level \\
\hline $3.4-5.0$ & High \\
\hline $1.8-3.3$ & Moderate \\
\hline $1.0-1.7$ & Low \\
\hline
\end{tabular}

Another statistical method used for data analysis was the paired-t test. The paired-t test involves the dependent sample, drawn in such a way that the observations in the first sample are directly related to the observations in the second sample, or they occur as pairs of values. The paired$t$ test is defined by:

$$
\text { Test value }=\frac{(\text { observed value })-(\text { expected value })}{\text { standard error }}
$$

where the observed value is the mean of differences, expected value $\mu_{D}$ is zero if the hypothesis is $\mu_{D}=0$.

The standard error is the standard deviation of the difference, divided by the square root of the sample size.

In addition, quantitative data analysis involves descriptive and inferential statistics are applied in this study. The Statistical Package Social Science (SPSS) Version 23.0 is used to analyse the scores and the students' interest towards Frog VLE.

\section{Results and Discussion}

In this study, the reliability test for the instrument is 0.824 which implies an excellent reliability value. A total of 40 students were involved in this study. 20 pupils were selected as control group and 20 pupils were selected as treatment group. The descriptive statistics of this study are summarized in the Table 4, showing that the control group consists of 12 male and 8 female students, while the experimental group consists of 11 male and 9 female students. Moreover, the primary school students assessed in the PKSR (Primary School Operational Evaluation) in both groups are also detailed in Table 4. 
Table 4. Demographics of the Respondents for Control and Experimental Groups

\begin{tabular}{|c|c|c|c|}
\hline & Variable & $\begin{array}{c}\text { Frequency } \\
(n=40)\end{array}$ & $\begin{array}{c}\text { Percentage } \\
(\%)\end{array}$ \\
\hline \multirow[t]{8}{*}{ Control } & Gender & & \\
\hline & Male & 12 & 60 \\
\hline & Female & 8 & 40 \\
\hline & $\begin{array}{c}\text { Grade of } \\
\text { Mathematics } \\
\text { in PKSR 1 }\end{array}$ & & \\
\hline & Grade A & 4 & 20 \\
\hline & Grade B & 7 & 35 \\
\hline & Grade C & 4 & 20 \\
\hline & Grade D & 5 & 25 \\
\hline \multirow[t]{8}{*}{ Experimental } & Gender & & \\
\hline & Male & 11 & 55 \\
\hline & Female & 9 & 45 \\
\hline & $\begin{array}{c}\text { Grade of } \\
\text { Mathematics } \\
\text { in PKSR 1 } \\
\end{array}$ & & \\
\hline & Grade A & 3 & 30 \\
\hline & Grade B & 9 & 35 \\
\hline & Grade C & 5 & 25 \\
\hline & Grade D & 3 & 10 \\
\hline
\end{tabular}

Table 4 shows the frequency and percentage of the respondents. To demonstrate the level of achievement of the control and treatment groups are almost the same, the mid-year examination of Mathematics (PKSR 1) in 2018 was analysed. For the control group, 4 students are found to obtain A, 7 students received $\mathrm{B}, 4$ students received $\mathrm{C}$ and 5 students received D. For the treatment group, 3 students received grade A, 9 students received B, 5 students get $\mathrm{C}$ and 3 pupils get $\mathrm{D}$. This analysis has shown that both control and treatment groups of respondents have approximately similar level of achievement in Mathematics subjects.

From the Table 5, the mean and proportion of each item in the questionnaire are being analysed. There are 40 completed questionnaires were used to calculate the mean and proportion of students who are using Frog VLE application to learn, and the results showed that $85 \%$ agreed with the fact that Frog VLE is user friendly; $82.5 \%$ found that learning through Frog VLE is fun; $80 \%$ agreed that Frog VLE is attractive; $82.5 \%$ enjoyed solving mathematical questions; $85 \%$ feels that concepts are easier to understand; $87.5 \%$ agreed with the fact that Frog VLE increase their interest towards Mathematics; 90\% used Frog VLE to communicate with teachers and friends; $85 \%$ feels that Frog VLE is effective for learning; 90\% feel excited to learn Mathematics using Frog VLE (see Table 5).

Table 5. Mean and proportion of the students in each scale

\begin{tabular}{|c|c|c|c|c|c|c|}
\hline Item & $\% \mathrm{SD}$ & $\% \mathrm{D}$ & $\%$ NDA & $\% \mathbf{A}$ & $\% \mathrm{SA}$ & $\begin{array}{l}\text { Mean } \\
\text { Score }\end{array}$ \\
\hline The Frog VLE is user friendly. & 0 & 2.5 & 12.5 & 50 & 35 & 4.2 \\
\hline Lesson with Frog VLE is fun. & $\mathbf{0}$ & $\mathbf{0}$ & 17.5 & 45 & 37.5 & 4.2 \\
\hline The Maths lesson through Frog VLE is very colourful and eye-catching. & 5 & $\mathbf{0}$ & 15 & 42.5 & 37.5 & 4.1 \\
\hline I enjoy doing Maths questions through Frog VLE. & $\mathbf{0}$ & $\mathbf{0}$ & 17.5 & 42.5 & 40 & 4.2 \\
\hline I easily understand division concept using Frog VLE. & $\mathbf{0}$ & 2.5 & 12.5 & 55 & 30 & 4.1 \\
\hline Learning using Frog VLE increase my interest in learning Maths. & $\mathbf{0}$ & $\mathbf{0}$ & 12.5 & 32.5 & 55 & 4.4 \\
\hline I communicate with my teachers and friends through Frog VLE. & $\mathbf{0}$ & $\mathbf{0}$ & 10 & 30 & 60 & 4.5 \\
\hline The features in Frog VLE is effective to use. & $\mathbf{0}$ & 2.5 & 12.5 & 45 & 40 & 4.2 \\
\hline Learning through Frog VLE excites me. & $\mathbf{0}$ & $\mathbf{0}$ & 10 & 25 & 65 & 4.6 \\
\hline
\end{tabular}

Note that $\mathrm{SD}=$ Strongly Disagree $; \mathrm{D}=$ Disagree $; \mathrm{NDA}=$ Neither Disagree nor Agree; $\mathrm{A}=$ Agree $;$ SA = Strongly Agree 
From the findings obtained in Table 5, the highest mean value for the items is last item which is "Learning through Frog VLE excites me". There are $90 \%$ of the students agreed that they are excites to learn Mathematics through Frog VLE. Only $10 \%$ of the pupils express uncertain and no students disagree with the item. This shows that most of the students used Frog VLE to communicate with teachers and friends via Frog VLE.

Another item with highest agreement is 9th item which is "I communicate with my teachers and friends through Frog VLE". Findings reveal that there are $90 \%$ of the students expressly agree on this item. While the mean value recorded for the 9th item is 4.5 and is interpreted as high level. This shows that most of the students use facilities that can communicate effectively with teachers and friends in the Frog VLE application.

However, the lowest mean value obtained is 4.1 which are the 3 th and 5 th items. The lowest mean value items are "The Maths lesson through Frog VLE is very colourful and eye-catching" and "I easily understand division concept using Frog VLE".

The effectiveness of the Frog VLE in teaching and learning were then tested using the paired-t test, and the results are detailed in the following tables. Table 6 shows the descriptive statistics for pre-test and post-test in the case of the control and experimental groups.

From the Table 6, Pair 1 is categorized as control group and Pair 2 is known as treatment group. The mean of the pre- and post-test for control group are 27.00 and 63.00 with 20 respondents. For treatment group, the mean for pre- and post-test are 25.00 and 69.00 .

Table 6. Descriptive Statistics for Control and Experimental Group

\begin{tabular}{|c|c|c|c|c|c|}
\hline & & Mean & $\mathrm{N}$ & $\begin{array}{c}\text { Std. } \\
\text { Deviation }\end{array}$ & Std. Error Mean \\
\hline \multirow{2}{*}{ Pair 1 } & Control_Pre & 27.00 & 20 & 9.921 & 2.218 \\
\cline { 2 - 6 } & Control_Post & 63.00 & 20 & 11.965 & 2.675 \\
\hline \multirow{2}{*}{ Pair 2 } & Exp_Pre & 25.00 & 20 & 9.597 & 2.146 \\
\cline { 2 - 6 } & Exp_Post & 69.00 & 20 & 14.382 & 3.216 \\
\hline
\end{tabular}

The analysis between pre-test and post-test achievement in the case of the control group, the alternative hypothesis is:

$H_{1}$ : There is a significant difference in student's academic achievement for pre-test and post-test in control group.

Table 7 depicts that there is a significant difference between the pre-test and post-test in the case of the control group $(t$ statistics $=-11.491, p<0.05)$. This is because students always learn Mathematics using conventional method.

In the case of the analysis between the pre-test and posttest of students' achievement for the experimental group, the alternative hypothesis is:

$H_{2}$ : There is a significant difference in students' academic achievement for the pre-test and post-test in the case of the experimental group.

Table 7. Paired-t Test for Control Group

\begin{tabular}{|c|c|c|c|c|c|c|c|c|}
\hline & \multirow{2}{*}{ Mean } & \multirow{2}{*}{ S.D. } & \multirow{2}{*}{$\begin{array}{c}\text { Std. Error } \\
\text { Mean }\end{array}$} & \multicolumn{2}{|c|}{ 95\% C.I. of Difference } & \multirow{2}{*}{$\mathrm{t}$} & \multirow{2}{*}{ df } & \multirow{2}{*}{ Sig (2-tailed) } \\
\hline & & & & Lower & Upper & & & \\
\hline Control_Pre-Control_Post & -36.00 & 14.01 & 3.133 & -42.56 & -29.44 & -11.49 & 19 & .000 \\
\hline
\end{tabular}

Table 8. Paired-t Test for Experimental Group

\begin{tabular}{|c|c|c|c|c|c|c|c|c|}
\hline & \multirow{2}{*}{ Mean } & \multirow{2}{*}{ S.D. } & \multirow{2}{*}{ Std. Error Mean } & \multicolumn{2}{|c|}{$95 \%$ C.I. of Difference } & \multirow{2}{*}{$\mathrm{t}$} & \multirow{2}{*}{ df } & \multirow{2}{*}{ Sig (2-tailed) } \\
\cline { 1 - 3 } & & & & Lower & Upper & & & \\
\cline { 1 - 1 } Exp_Pre - Exp_Post & -44.0 & 16.51 & 3.69 & -51.73 & -36.27 & -11.92 & 19 & .000 \\
\hline
\end{tabular}


For the experimental group, Table 8 shows that there is a significant difference between pre-test and post-test for the application of Frog VLE in the learning process. Although both the control and experimental groups are significantly different in its pre- and post-test $(t$ statistics $=$ $-11.92, p<0.05$ ), the mean difference for the application of Frog VLE in a classroom is larger than conventional teaching and learning, because most students prefer to use Frog VLE in the classroom, reporting that it is effective in helping them to learn (see Table 5).

The activities that use Frog VLE in teaching and learning process can enhance visual-space skills of a student as well as increase their interest towards Mathematics. Frog VLE also ensures a fun learning atmosphere which involves feeling and emotion. This will indirectly encourage lifelong learning for them.

Apart from this, teachers need to take the initiative to apply Frog VLE applications during the teaching and learning process. This is because some of the teachers who have low self-efficacy and less interested in applying Frog VLE in teaching process. Teachers need to develop their teaching planning in order to optimize the use of Frog VLE in teaching and learning process. According to Khasiman [26], the findings showed that there are still many teachers lack of information and communication skills. The situation became more serious when the school administrators themselves did not cooperate with the teachers who were teaching using the Frog VLE. Without the support from the administrators, Frog VLE cannot be effectively implemented in the classroom because it requires efficient infrastructure. Thus, teachers need to follow courses organized by the government agencies to improve their knowledge and skills on Frog VLE. In addition, time constraints, limited internet access and teacher workloads are other factors that challenge the use of Frog VLE applications in the classroom. A study conducted by Norazilawati et al. [27] also supported that there is a challenge where students' laziness and not willing to try will affect students' performance when using Frog VLE application.

\section{Conclusions}

Frog VLE is a virtual learning management system based on a student-centered learning. The planned activities, modules, videos, and assignments can be integrated into Frog VLE to enhance visual-space skills, as well as develop emotional excitement and increased interest. Frog VLE also ensures a fun learning atmosphere. The findings confirmed that the majority of the students prefer to use Frog VLE in teaching and learning, as it captures their interest and increased their learning interest in mathematics. The findings revealed that there is a significant difference between the pre-test and post-test for both the conventional approach and using Frog VLE application. However, the mean difference is larger for the Frog VLE application.
Hence, it can be concluded that the Frog VLE application is an effective teaching material that can be used to enhance students' understanding and increase their interest towards Mathematics. In addition, the Frog VLE application also provides students with the opportunity to acquire knowledge and access materials such as pictures, video or games that related to the topics at any time. The suggestion for further study is the comparison of Frog VLE and other teaching methods such as Google classroom, YouTube, games, smart classroom, etc.

\section{Acknowledgements}

The authors would like to extend their gratitude to the Research Management and Innovation Centre (RMIC), Sultan Idris Education University (UPSI) for the University Research Grants (code: 2018-0150-106-01) that helped fund the research.

\section{REFERENCES}

[1] A. A. Ahmed, N. H. Zakaria, A. H. Elmi. An Evaluation of Virtual Learning Environment Readiness in Higher Education Institutions (HEIs), Journal of Information Systems Research and Innovation, Vol. 2, 86-94, 2013.

[2] Malaysia Education Blueprint (KPM 2013). Malaysia Education Blueprint 2013-2025: Preschool to PostSecondary Education, Kementerian Pendidikan Malaysia, Malaysia, 2013.

[3] S. Lyndon, B. Hale. Evaluation of How the Blended Use of a Virtual Learning Environment (VLE) Can Impact on Learning and Teaching in a Specific Module, Enhancing Learning in the Social Sciences, Vol. 6, No. 1, 56-65, 2014.

[4] M. S. Chan, N. M. M. Zainuddin, N. Maarop, S. Yaacob, N. Z. Rahim, W. A. W. Hassan. Design of Frog Virtual Learning Environment (Frog VLE) Aesthetics Model for Malaysia Primary Schools, Open International Journal of Informatics, Vol. 5, No. 1, 23-31, 2017.

[5] G. Robinson, L. M. Basco, Y. Mathews, R. Dancel, M. A. Princena, M. J. Mc Keever. ESL Student Perceptions of VLE Effectiveness at a University in South Korea, Journal of Language Teaching and Research, Vol. 8, No. 5, 847-857, 2017.

[6] N. H. Siaw, F. U. Agatha. A Pilot Study on Factors Affecting the Use of Frog Virtual Learning Environment, Jurnal Penyelidikan IPG KBL, Vol.12, 1-17, 2015.

[7] T. S. Hew. Explicating The Acceptance of Virtual Learning Environment: The Roles of Channel Expansion and The Theory of Self Determination, Thesis, University of Malaya, Malaysia, 2017.

[8] N. Z. Razali, Z. Bahador, M. K. Saidon. Faktor-faktor yang mempengaruhi penggunaan VLE FROG dalam kalangan guru di Sekolah Menengah, Proceedings of the ICECRS, Vol. 1, No. 1, 1023-1032, 2017. 
[9] A. Chetwynd. VLE based analysis and design, The Plymouth Student Scientist, Vol. 10, No. 1, 102-142, 2017.

[10] M. L. Cheok, S. L. Wong, A. F. Ayub, R. Mahmud. Teachers' Perceptions of E-Learning in Malaysian Secondary Schools, Malaysian Online Journal of Educational Technology, Vol. 5, No. 2, 20-33, 2017.

[11] S. Y. Phoong, S. W. Phoong, X. J. Tan. A Mediation Analysis on Level of Education and Economic Growth, The Journal of Social Sciences Research, Vol. 6, No. S, 417-422, 2018.

[12] K. T. Yang, T. H. Wang. Interactive White Board: Effective Interactive Teaching Strategy Designs for Biology Teaching. Tech, E-Learning-Engineering, On-Job Training and Interactive Teaching, 139- 154, 2012.

[13] R. Jamieson-Proctor, P. Albion, G. Finger, R. Cavanagh, R. Fitzgerald, T. Bond, P. Grimbeek. Development of the TTF TPACK Survey Instrument, Australian Educational Computing, Vol. 27, No. 3, 26-35, 2013.

[14] S. So. Refined "Chalk-and-Talk" of lecture content: teaching signals and systems at the Griffith school of engineering, The Australasian Association for Engineering Education Annual Conference, Melbourne, Australia, 2012.

[15] T. Shah, M. A. Patel, H. Shah. A Comparative Study on the Teaching Effectiveness of Chalk \& Talk Versus Microsoft PowerPoint Presentation-An Institution Based Pilot Study of Physiotherapy Students, International Journal of Current Research and Review, Vol. 9, No. 11, 40-43, 2017.

[16] N. Jabeen, A. Ghani. Comparison of The Traditional Chalk and Board Lecture System Versus Power Point Presentation as a Teaching Technique for Teaching Gross Anatomy to The First Professional Medical Students, Journal of Evolution of Medical and Dental Sciences, Vol. 4, No. 11, 1811-1817, 2015.

[17] M. D. L. Mata, V. Monteiro, F. Peixoto. Attitudes towards Mathematics: Effects of Individual, Motivational, and Social Support Factors, Child Development Research, 1-10, 2012.

[18] H. Mahizer, Y. Mohd Azli. Frog VLE (Persekitaran Pembelajaran Maya) dalam Pengajaran dan Pembelajaran: penerimaan dan kaedah pelaksanaannya, Journal of Research, Policy and Practice of Teachers \& Teacher Education, Vol. 6, No. 2, 67-77, 2016.

[19] K. Termit, H. Noorma. Teachers' readiness to utilize Frog VLE: A case study of a Malaysian secondary school, British Journal of Education, Society \& Behavioural Science, Vol. 5, No. 1, 20-29, 2015.

[20] Online Available: Rheingold H, 2004, Mobile Social Presence: Who Knows Who's Where Now? Online available from https://www.thevirtualhandshake.com/2004 /05/06/mobile-social-presence-who-knows-whos-wherenow/

[21] N. Kumarawel, F. D. Yusop, R. A. Razak. Mobile learning for teaching and learning Science, Technology, Engineering and Mathematics (STEM): A review of literature Proceedings of the International Congress on Economics, Social Sciences and Information Management, Bali, Indonesia, 2015.
[22] E. P. John, L. L. Rowley, S. Hu. Diversity and Leadership: A Study of High-Achieving Students of Color, The Journal of Negro Education, Vol. 78, No. 1, 17-28, 2009.

[23] Online Available: FrogAcademy, 2014, What is FrogAcademy? Online available from https://frogasia.com/ learncentre/?page_id $=7278$

[24] W. L. Neuman. Social research methods: qualitative and quantitative approaches, 4th Edition, Allyn \& Bacon, Boston, 2000.

[25] W. P. Jr. Fisher. Rasch Measurement Transaction, Transaction of the Rasch Measurement SIG American Educational Research Association, Vol.21, No.1, 1095, 2007.

[26] Online Available: Khasiman SA, 2013, Tinjauan awal penggunaan frog vle di sekolah, Online available from http://sekolahpenandaaras.wordpress.com

[27] A. Norazilawati, M. N. Noraini, N. A. N. Yusuf, M. Rosnidar. Aplikasi persekitaran pengajaran maya (FROF VLE) dalam kalangan Guru Sains, Jurnal Pendidikan Sains \& Matematik Malaysia, Vol. 3, No. 2, 63-76, 2013. 